\title{
Molecular Cloning of $\alpha$ RYR Hotspot Region 1 from Broiler Chicken
}

\author{
Iris Lamberti Ziober ${ }^{1}$, Fernanda Gonzales Paião ${ }^{1}$, Silvana Regina Rockenbach Marin ${ }^{2}$, \\ Denis Fabricio Marchi ${ }^{1}$, Eliseu Binneck ${ }^{2}$, Alexandre Lima Nepomuceno ${ }^{2}$, Luiz Lehmann \\ Coutinho $^{3}$ and Massami Shimokomaki ${ }^{1 *}$ \\ ${ }^{1}$ Departamento de Ciência e Tecnologia de Alimentos; Centro de Ciências Agrárias; Universidade Estadual de \\ Londrina; C. P.: 6001; 86051-970; Londrina - PR - Brasil. ${ }^{2}$ Embrapa Centro Nacional de Pesquisa de Soja; \\ 86001-970; Londrina - PR - Brasil. ${ }^{3}$ Laboratório de Biotecnologia Animal; Escola Superior de Agricultura "Luiz \\ de Queiroz"; Universidade de São Paulo; 13418-900; Piracicaba - SP - Brasil
}

\begin{abstract}
Samples of Pectoralis major $m$. were collected, and an RT-PCR analysis of the $\alpha$-Ryanodine receptor $(\alpha R Y R)$ from chicken mRNA hotspot region spanning aminoacid residues 386 to 540, numbered according to the turkey sequence, revealed two classes of transcripts. The sequences of the first class were similar to turkey and human with $97 \%$ and $74 \%$ of identity, respectively, and included all transcripts with substitutions in the nucleotide sequence. The second class was characterized by the deletion of nucleotides, leading to a premature stop codon and coding for a truncated and nonfunctional protein. These results are to date the first report related to the sequencing of the chicken $\alpha \mathrm{RYR}$ hotspot region 1, which will possibility serve as a guide for further studies regarding a solution in the poultry production chain related to the problem of pale, soft and exudative (PSE) meat.
\end{abstract}

Key words: $\alpha$ RYR, PSE, chicken

\section{INTRODUCTION}

The modern broiler is a result of genetic selection driven by the economic need to produce birds with greater muscle mass and a quicker growth rate (Barbut et al., 2008, Oda et al., 2009). However, to date little consideration has been given to examining the impact that this genetic selection for rapid growth and muscle mass gain has on muscle development. Pale, Soft and Exudative (PSE) broiler meat has been a major concern for the meat industry, and efforts have been devoted to determining its origin and developing techniques to avoid the formation of this abnormality (Olivo et al., 2001; Guarnieri et al. 2004; Barbut et al., 2008, Marchi et al., 2009; Simões et al., 2009a,b; Soares et al., 2009). PSE meat occurs due to postmortem rapid glycolysis associated with a quick $\mathrm{pH}$ drop while the carcass is still hot (Bendal and Wismer-Perdersen, 1962). This association between $\mathrm{pH}$ and high temperature causes meat protein denaturation, impairing the functional properties of muscle protein and giving rise to meat surface exudates (Candek-Potokar et al., 1998; Olivo et al., 2001). The ryanodine receptor (RyR) is a protein of approximately 5000 amino

\footnotetext{
* Author for correspondence: mshimo@uel.br
} 
acids that forms a large intracellular channel in the sarcoplasmic reticulum (SR) of skeletal muscle cells (Sutko and Airey, 1996). It plays a role in the rapid release of $\mathrm{Ca}^{2+}$ from the SR during excitation-contraction (e-c) coupling (MacLennan, 2000). The RyR protein family, which includes three isoforms (RyR1, RyR2 and RyR3), is largely studied because of its importance to the pathogenic mechanisms of various diseases, such as malignant hyperthermia and central core disease in humans (Brini, 2004). In pigs, defects in RYR1 gene lead to a special condition known as Porcine Stress Syndrome (PSS) that produces PSE pork meat (Fujii et al., 1991). In turkeys, a similar problem occurs, and PSE meat is also produced (Chiang et al., 2004), although Avian Stress Syndrome symptoms still await characterization. In mammals, the major $\mathrm{Ca}^{2+}$ release gene expressed in fast- and slow-twitch skeletal muscle is RYR1 (MacLennan, 2000), while in birds, the major genes expressed in a ratio of $1: 1$ are RYR 1 and RYR3 (commonly called $\alpha$ RYR and $\beta R Y R$, respectively) (Ottini et al., 1996; Sutko and Airey,
1996). A differential expression of RYR isoforms was reported in chicken skeletal muscle cells by Oda et al. (2009), who identified a relatively lower value for $\beta R Y R$ in animals that developed PSE compared to $\alpha \mathrm{RYR}$, suggesting this could be one possible mechanism involved in the development of broiler PSE meat. To date, no reliable genetic marker for meat quality has been defined by the poultry industry (Barbut et al., 2008); nevertheless, the study of candidate regions of RYR1 (Fig. 1) is likely to be one of the best ways to identify a marker that would provide a rapid response to selection (Barbut et al. 2008).

As seen in Figure 1, hotspot region 1 is a polypeptide subunit forming a protein structure: a large N-terminal region located at the cytoplasm. This region plays an important role in e-c coupling through its interaction with dihydropyridine receptors (DHPRs). DHPRs are L-type voltagegated $\mathrm{Ca}^{2+}$ channels that are present in the outer membranes of muscle cells and control the opening of RyR1 (Protasi et al., 2002).

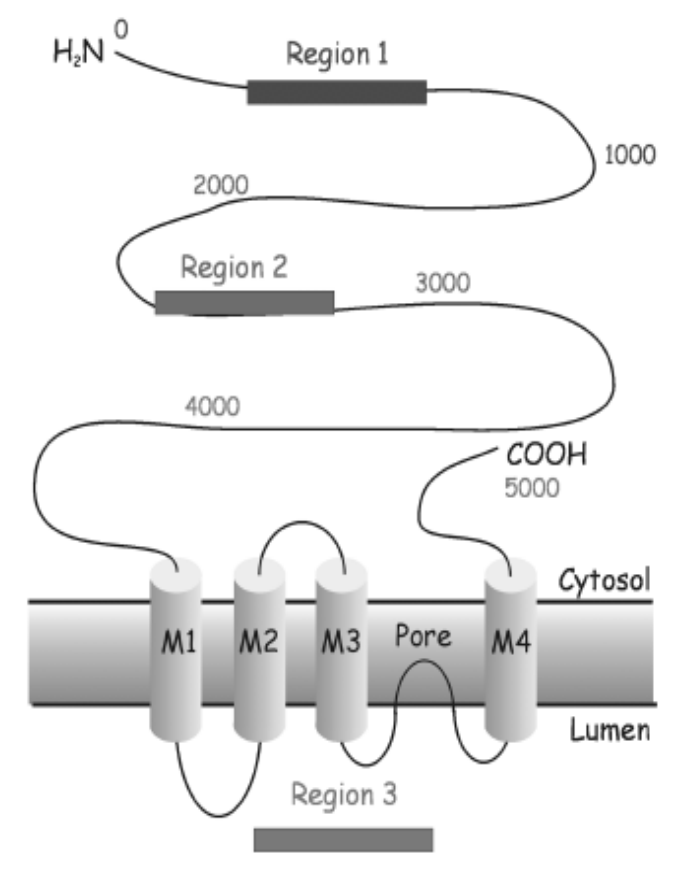

Figure 1 - Schematic diagram for the hotspot regions (1-3) and the predicted transmembrane domain (M1-M4) of RYR1. Adapted from Brini (2004). 
In mutated pig muscles, one alteration at this region, mediated by a substitution (Arg615Cys) in the RyR1 protein, causes gating hypersensitivity of the ryanodine receptors and channel openings are facilitated and closings are inhibited (Fujii et al., 1991). $\mathrm{Ca}^{2+}$ is released from the $\mathrm{SR}$ at a rate equivalent to twice that of normal muscle (Cheah and Cheah, 1976). The physiological effect of this mutation on RYR1 is an elevation of $\mathrm{Ca}^{2+}$ levels in resting muscle. It has been shown in pig that an elevated resting $\mathrm{Ca}^{2+}$ level before slaughter promotes muscle hypermetabolism and leads to muscle heat production and acidosis. The combination of these two factors causes postmortem protein denaturation and a significant deterioration in meat quality. Although this fact is well known in pigs, the genetic basis of PSE in poultry is not currently well understood. The aim of this work was to sequence and analyze the broiler chicken species (Gallus gallus) hotspot region 1 of $\alpha$ RYR mRNA.

\section{MATERIALS AND METHODS}

Seventy-five 42-day-old birds from a commercial line were manually slaughtered under laboratory conditions by cutting the carotid artery and jugular vein without previous electrical stunning. Just after bleeding, muscle samples $\left(0.5 \times 2.0 \times 1.0 \mathrm{~cm}^{3}\right)$ were collected and stored in microtubes $(1.5 \mathrm{~mL})$, rapidly frozen in liquid nitrogen and stored at $80^{\circ} \mathrm{C}$. Total RNA was extracted from Pectoralis major $\mathrm{m}$. based on the method developed by Chomczynski and Sacchi (1987). The cDNA was obtained through reverse transcription with SuperScript III RNase $\mathrm{H}^{-}$Reverse Transcriptase (Invitrogen, Carlsbad, CA), following the manufacturer's instructions.

For PCR amplification, the primers were the same used by Chiang et al. (2004) for turkey (Meleagris gallopavo), with the following sequences: 5'-CTG CAC CAG GAG GGC CAC ATG GAC GA-3' (forward) and 5'-CGG TCC AGT TTG CTG ACC AGC CAG TCC AGG-3' (reverse). The PCR amplification consisted of an initial denaturation at $95^{\circ} \mathrm{C}$ for $2 \mathrm{~min}$, followed by 35 cycles at $95^{\circ} \mathrm{C}$ for $30 \mathrm{~s}, 64.5^{\circ} \mathrm{C}$ for $30 \mathrm{~s}$, and $72^{\circ} \mathrm{C}$ for $1 \mathrm{~min}$, and a final extension at $72^{\circ} \mathrm{C}$ for $8 \mathrm{~min}$. PCR confirmation was conducted by agarose gel electrophoresis, and the amplified fragments were cut from the gel and purified using the PureLink ${ }^{\mathrm{TM}}$
Quick Gel Extraction Kit (Invitrogen, Carlsbad, CA) following the manufacturer's instructions. All PCR products were inserted into the TOPO TA Cloning® vector (Invitrogen, Carlsbad, CA) following the manufacturer's instructions and transformed using DH5 $\alpha$ eletrocompetent cells. The recombinant clones were isolated and sequenced on both strands using the M13 universal primers and the BigDye ${ }^{\circledR}$ Terminator v3.1. kit (Applied Biosystems, Warrington, UK) for the automatic sequencer ABI 3100 (Applied Biosystems, Warrington, UK).

The chromatograms obtained were manually analyzed using the program Vector NTI Suite 8 (InforMax), followed by removal of the vector sequence (Vector Screen (http://www.ncbi.nlm.nih.gov/VecScreen/VecScre en.html), and finally global alignment using ClustalW2

(http://www.ebi.ac.uk/Tools/clustalw2/index.html) to obtain the consensus sequence.

\section{RESULTS AND DISCUSSION}

As described by Fujii et al. (1991) and Chiang et al. (2004), the N-terminal region of $\alpha R Y R$ is the hotspot that leads to alterations and has the potential to promote the PSE problems observed in pigs and turkeys, respectively. In broiler chicken, this sequence was obtained through the primers originally designed for turkey (Chiang et al. 2004). The PCR products of evaluated samples had a similar size of approximately $600 \mathrm{bp}$. The electrophoresis profile pattern is shown in Fig. 2.

The sequence reported herein is between nucleotides \#1155 - 1622 from the $\alpha \mathrm{RYR}$ of turkey (GenBank accession number: EU177005.1), which has the complete coding sequence available. Moreover, the $\alpha$ RYR chicken transcripts did not show any similarity when compared to chicken $\alpha$ RYR sequences deposited in the GenBank database: they are located between nucleotides \#9204 - 9436 for XM_424193, \#12150 - 12297 for XM_428139, \#12300-12710 for XM_427376, and \#13242-15153 plus 142 nucleotides for X95266; the latter was the first reported $\alpha$ RYR sequence of chicken (Ottini et al., 1996). All sequences were compared to the $\alpha R Y R$ sequence from turkey (EU177005.1). 


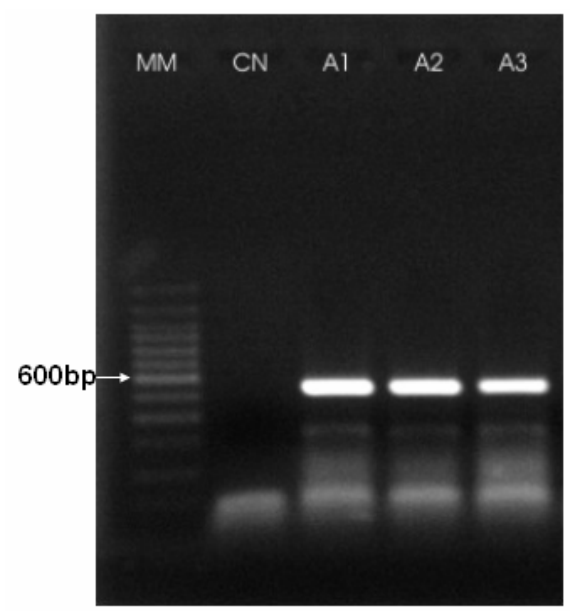

Figure 2 - Electrophoresis in 1\% agarose gel. Amplification of hotspot region 1 of the $\alpha \mathrm{RYR}$ in chicken. MM: 100 bp DNA Molecular Mass Ladder; CN: negative control; A1, A2, A3: samples.

The hotspot region 1 of the identified chicken $\alpha \mathrm{RYR}$ showed $94 \%$ homology to the same region in the turkey sequence, $74 \%$ to some mammalian species (pig, horse, dog, rabbit) and $72 \%$ to the human sequence, according to the BLAST software (Basic Local Alignment Sequence Tool) (Altschul et al., 1990).

All 75 samples presented high similarity to each other, and the most common and frequent sequence was deposited at NCBI GenBank (GQ337080). Sixty polymorphisms were detected in the transcript variants. Comparing the new sequence of chicken $\alpha$ RYR (hotspot 1) in an alignment of the protein between different species, a high degree of homology was observed. These 155 amino acid residues, obtained from translation of chicken cDNA amplified in this work, were highly conserved compared to turkey $\alpha$ RyR (97\% homology), but were less conserved when compared to RyR1s of mammalian species (Fig. $3)$.

All 75 chicken $\alpha \mathrm{RYR}$ transcript sequences belonged to the pfam 01365 domain, which is called the RIH (RyR and IP3R Homology)

domain. This is an extracellular domain, which can be part of two types of calcium channels: the RyR and the inositol 1,4,5- trisphosphate receptor $\left(\mathrm{IP}_{3}\right)$ (Sanger Institute, 2009).

So far, to our knowledge, this is the first report of substitutions or deletions in the hotspot region 1 of the chicken $\alpha$ RYR gene.
In order to verify whether some of the alterations within the nucleotide and amino acid sequences would cause changes at the protein structure level, the SIFT (Sorting Intolerant From Tolerant http://sift.jcvi.org/) program was used. This program can predict whether the substitution of one amino acid will affect the protein function based on the sequence similarity and the amino acids physicochemical properties.

The Fig. 4 shows the variation of amino acid substitutions and different transcript variants from chicken Pectoralis major $\mathrm{m}$. In all transcript variants shown in Fig. 3, the amino acid substitutions are tolerated, according to the SIFT program. However, we found some transcripts that had one or more amino acid substitutions that would lead to probable changes within the protein function.

Chiang et al. (2004) also found three transcript variants in turkeys; two of them had deletions in the nucleotide sequence, which led to a deletion in exons, and the third had the normal sequence.

The substitutions or deletions in the nucleotide sequence of RYR similar to those reported in this experiment were also described by Chiang et al. (2007); however, these changes were observed in the turkey $\beta R Y R$ sequence. These alterations were characterized as SNPs (Single Nucleotide Polymorphisms), although any of the SNPs led to alterations in the primary structure of the protein. 
The transcript GD269030 and others that had a nucleotide deletion, which created a premature stop codon, resulted in a truncated protein. However, the mRNAs that would produce truncated proteins are degraded by the NMD (Nonsense-mediated mRNA decay) pathway (Chang et al., 2007).

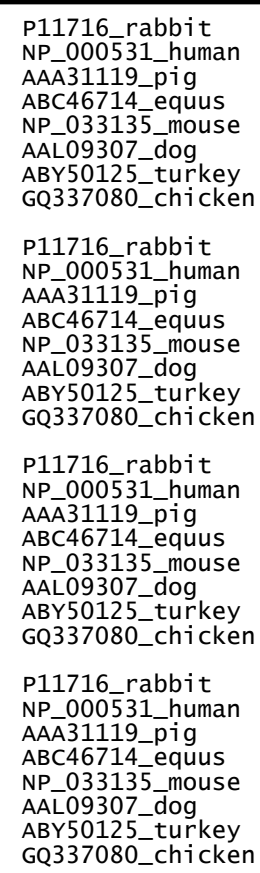

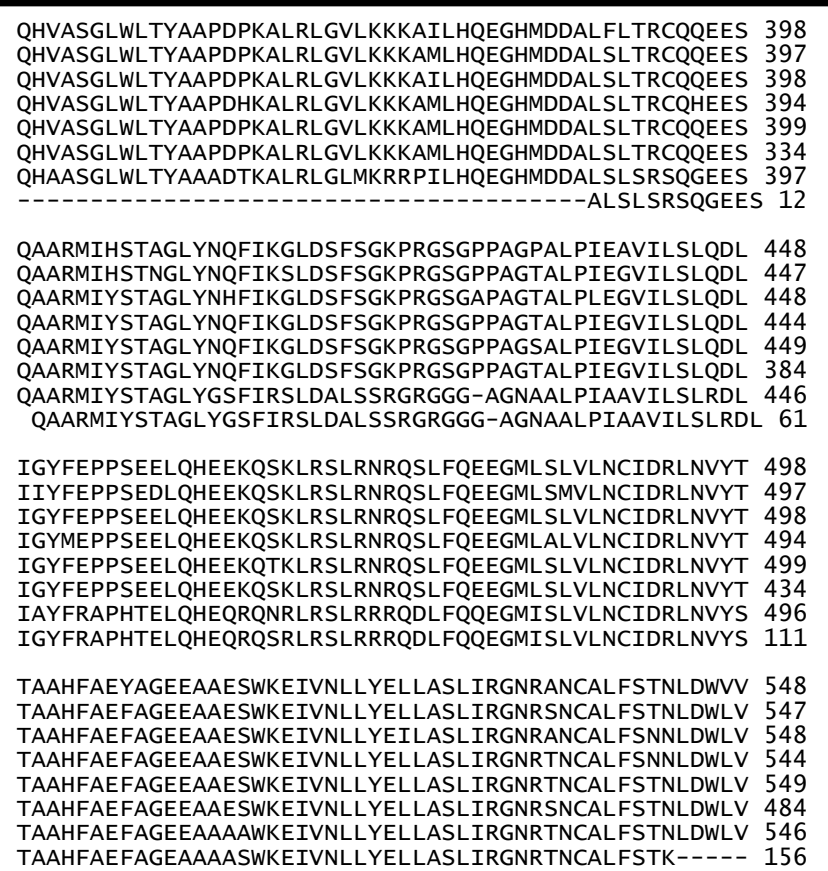

Figure 3 - Alignment of chicken $\alpha$ RyR amino acid sequence with published skeletal muscle RyR $\alpha$ and 1 isoforms from different species.

\begin{tabular}{|c|c|}
\hline $\begin{array}{l}\text { GD269029 } \\
\text { GD269030 } \\
\text { GD269028 } \\
\text { GD269021 } \\
\text { GD269022 } \\
\text { GD269023 } \\
\text { GD269024 } \\
\text { GD269025 } \\
\text { GD269031 } \\
\text { GD269027 } \\
\text { GD269026 }\end{array}$ & 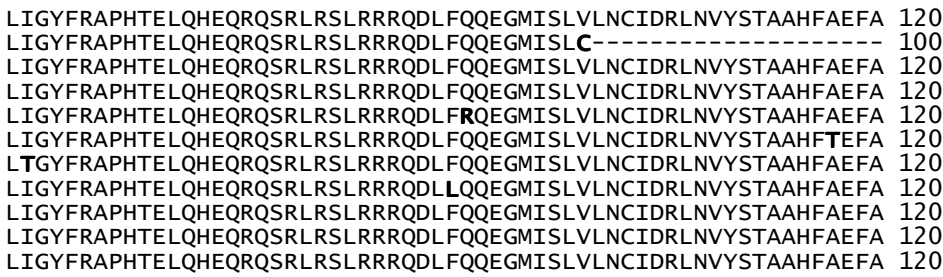 \\
\hline
\end{tabular}

Figure 4 - Partial global alignment of the RyR1 protein from some of the new transcripts. Amino acid changes are in bold.

This pathway is able to detect the mRNAs that have premature termination codons (UAA, UAG, UGA), and these nonsense mRNAs are degraded and no protein is produced (Culbertson, 1999; Chang et al., 2007). Yet, this pathway does not seem to work when the mutations occur at the 3' end of the gene (Culberston, 1999).

The alterations observed in this study do not correlate with those found by Fujii et al. (1991) in pigs. In sensitive pigs, there is an exchange of amino acid 615 (an arginine to a cysteine) due to a point mutation in the cDNA on nucleotide \#1843, where a cytosine is replaced by a thymine, leading to PSE. The animals with this mutation are prone to develop PSS and consequently PSE meat (Fujii et al. 1991).

Therefore, it can be concluded that the amplified region of $468 \mathrm{bp}$, as part of a total $\alpha \mathrm{RYR}$ gene of 
approximately $15,000 \mathrm{bp}$, could serve as a guide for further and directed studies towards the solution of abnormalities in the poultry meat chain. As has been previously reported, meat quality problems such as PSE have been strongly correlated to this gene in pigs and turkeys (Fujii et al., 1991; Chiang et al., 2004).

\section{ACKNOWLEDGEMENTS}

This work was funded by $\mathrm{CNPq}$ and Fundação Araucária/CNPq Pronex (Protocol \# 09.277) and Fundação Araucaria/Finep under the BioAgroPar Program. We would also like to thank CNPq and the CAPES Foundation for a graduate scholarship to ILZ and DFM, respectively. ALN, LLC and MS are CNPq Research Fellows. FGP is under a PostDoctorate CNPq Scholarship Program (Process CNPq 151809/2008-9).

\section{RESUMO}

Amostras do músculo Pectoralis major foram coletadas e uma RT-PCR foi conduzida para avaliar a sequência do mRNA do $\alpha$ RYR, região compreendida entre os resíduos de aminoácido 386-540, numerado de acordo com a sequência de perus. Os resultados revelaram duas classes de transcritos. O primeiro teve $97 \%$ e $74 \%$ de identidade com as sequências de $\alpha$ RyR e RyR1 de perus e humanos, respectivamente, e incluiu todos os transcritos com substituições de nucleotídeos. A segunda classe de transcritos foi caracterizada pela deleção de bases que levaram a um stop códon prematuro e a uma proteína truncada nãofuncional. Esses resultados são até o momento, o primeiro relato de sequenciamento do $\alpha \mathrm{RYR}$, região hotspot 1 de frangos e podem servir como guia para estudos futuros na tentativa de se encontrar uma solução para os problemas na cadeia de produção de frangos relacionados com as carnes PSE (pálida, flácida e exsudativa).

\section{REFERENCES}

Altschul, S. F.; Gish, W.; Miller, W.; Myers, E. W.; Lipman, D. J. (1990), Basic local alignment search tool. J Mol Biol. 215, 403-410

Barbut, S., Sosnicki, A. A., Lonergan, S. M., Knapp, T., Ciobanu, D. C., Gatcliffee, L. J., Huff-Lonerganc, E., Wilson, E. W. (2008), Progress in reducing the pale, soft and exudative (PSE) problem in pork and poultry meat. Meat Sci., 79, 46-63

Barbut, S. (2009), Pale, soft, exudative poultry meat Reviewing ways to manage at the processing plant. Poultry Sci., 88, 1506-1512

Bendall, J. R.; Wismer-Pedersen, J. (1962), Some properties of the fibrillar proteins of normal and watery pork muscle. J. Food Sci., 24, 144-457

Brini, M. (2004), Ryanodine receptor defects in muscle genetic diseases. Biochem. Biophys. Res. Comm., 322, 1245-1255

Candek-Potokar, M.; Zlender B.; Lefaucheur L.; Bonneau M. (1998), Effects of age and/or weight at slaughter on longissimus dorsi muscle: biochemical traits and sensory quality in pigs. MeatSci., 48, 287300

Chang, Y.-F.; Imam, J. S.; Wilkinson, M. F. (2007), The nonsense-mediated decay RNA surveillance pathway, Annu. Rev. Biochem, 76, 51-74

Cheah, S. K and Cheah, A. M. (1976), The trigger for PSE condition in stress-susceptible pigs.J.Sci.Food Agri., 27, 1137-1144.

Chiang, W.; Allison, C. P.; Linz, J. E.; Strasburg, G. M. (2004), Identification of two. $\alpha$ RYR alleles and characterization of alpha RyR transcript variants in turkey skeletal muscle. Gene, 330, 177-184

Chiang, W.; Yoon, H-J; Linz, J. E.; Airey, J. A.; Strasburg, G. M. (2007), Divergent mechanisms in generating molecular variations of $\square$ RYR and $\square$ RYR in turkey skeletal muscle. J Muscle Res Cell Motil, 28, 343-354

Chomcznski, P. and Sacchi, N. (1987), Single step method method of RNA isolation by acid guanidinium thiocyanate-phenol-chloroform extraction. Anal. Biochem., 162, 156-159

Culbertson, M. R. (1999), RNA surveillance unforseen consequences for gene expression, inherited genetic disorders and cancer. Trends Gen., 15, 74-80

Fujii, J.; Otsu, K.; Zorzato, F.; Leon, S.; Khanna, V.K.; Weiler, J.E; O`Brien, P.J.; MacLennan, D.H. (1991), Identification of a mutation in porcine ryanodine receptor associated with malignant hypertermia. Science, 253, 448-451 
Guarnieri, P. D.; Olivo, R.; Soares, A. L.; Olivo, R.; Schneider, J. P.; Macedo, R. M.; Ida, E. I.; Shimokomaki, M. (2004), Preslaughter handling with water shower spray inhibits PSE (Pale, Soft, Exudative) broiler breast meat in a commercial plant. Biochemical and ultrastructural observations. J. Food Biochem., 28, 269-277

MacLennan, D. H. (2000), $\mathrm{Ca}^{2+}$ signalling and muscle disease. Eur. J. Biochem., 267, 5291-5297

Marchi, D.F., Oba, A., Ziober, I. L., Soares, A. L., Ida, E. I., Shimokomaki, M. (2009), Development of a gas chamber for detecting broiler chicken halothane sensitivity and PSE (Pale, Soft, Exudative) meat formation. Braz. Arch. Biol. Technol., submited

Oda, S. H. I.; Nepomuceno, A. L.; Ledur, M. C.; Oliveira, M. C. N.; Marin, S. R. R.; Ida, E. I.; Shimokomaki M. (2009), Quantitative differential expression of alpha and beta ryanodine receptor genes in PSE (Pale, Soft, Exudative) meat from two chicken lines: broiler and layer. Braz. Arch. Biol.Technol., in press

Olivo, R.; Soares, A. L.; Ida, E. I.; Shimokomaki, M. (2001), Dietary Vitamin E Inhibits Poultry PSE and Improves Meat Functional Properties. J. Food Biochem., 25, 271-283

Ottini, L.; Marziali, G.; Conti, A.; Charlesworth, A.; Sorrentino, V. (1996), $\alpha$ and $\beta$ isoforms of ryanodine receptor from chicken skeletal muscle are the homlogues of mammalian RyR1 an RyR3. Biochem. J., 315, 207-216

Protasi, F.; Paolini, C.; Nakai, J.; Beam, K.G.; FranziniArmstrong, C.; Allen, P.D., (2002), Multiple regions of RyR1 mediate functional na structural interactions with $\alpha_{1 S}$-dihydropyridine receptors in skeletal muscle. Bioph. J., 83, 3230-3244
Sambuughin, N.; Mcwilliams, S.; De Bantel, A.; Sivakumar, K.; Nelson, T.E. (2001), Single-aminoacid deletion in the RYR1 gene, associated with malignant hyperthermia susceptibility and unusual contraction phenotype, Am. J. Hum. Genet., 69, 4-8

Sanger Institute,

(2009), http://pfam.sanger.ac.uk/family?PF01365. Accessed: April, 25, 2009.

Simões, G. S.; Rossa, A.; Oba, A.; Matsuo, T.; Shimokomaki, M.; Ida, E. I.; (2009a), Transporte e Ocorrência de PSE (Pale, Soft, Exudative) e DFD (Dark, Firm, Dry) em Filés de Peito de Frango durante o Inverno. Rev. Nac. Carne, São Paulo, 23, 20-30

Simões, G. S.; Oba, A.; Matsuo, T.; Rossa, A.; Shimokomaki, M.; Ida, E. I. (2009b), Vehicle thermal microclimate evaluation during Brazilian summer broiler transport and the occurrence of pse (pale, soft, exudative) meat. Braz. Arch. Biol. Technol., submited Soares, A. L., Marchi, D. F., Matsushita, M., Guarnieri, P. D., Droval, A., Ida, E. I. and Shimokomaki, M. (2009), Lipid oxidation and changes in fatty acids profile related to broiler breast meat colour abnormalities. Braz. Arch. Biol. Technol., accepted for publication

Sutko, J.L.; Airey, J. A. (1996), Ryanodine receptor $\mathrm{Ca}^{2+}$ release channels: does diversity in form equal diversity in function? Physiol. Rev., 76, 1027-1071 
Página Em

Branco 